\title{
Antioxidant and Antimicrobial Properties of the Fir Buds Syrup
}

\author{
Liana-Mariana DEAC, Anca FĂRCAȘ, Dan C. Vodnar, Maria TOFANĂ, Sonia A. SOCACI* \\ Faculty of Food Science and Technology, University of Agricultural Sciences and Veterinary Medicine Cluj-Napoca, \\ Romania \\ corresponding author: sonia.socaci@usamvcluj.ro
}

Bulletin UASVM Food Science and Technology 71(1) / 2014

ISSN-L 2344-2344; Print ISSN 2344-2344; Electronic ISSN 2344-5300

\begin{abstract}
The fir buds as well as the fir buds extracts (such as fir buds syrup) are used in traditional medicine and phytotheraphy for the alleviation of light to medium forms of respiratory diseases and for the prophylaxis or treatment of some childhood disorders. The antioxidant and antimicrobial properties of the two types fir buds syrups (cold pressed and boiled) taken into study were demonstrated by its content in vitamin C, flavonoids and by the inhibitory effect on E.coli, B. cereus, S.aureus, L. monocytogenes, Salmonella thypi.
\end{abstract}

Keywords: fir buds syrup, vitamin C, flavonoids, antioxidant capacity, antimicrobial properties

Introduction. The fir tree, Abies alba, is a monoecious tree from Pinaceae family, found in hilly and mountainous areas from our country. Beside its importance for the wood and cellulose industry, the fir buds have several uses in food and cosmetic industry as well as in phytotheraphy and traditional medicine due to their content in different bioactive compounds. The fresh or dried fir buds are used, from ancient times, in the preparation of an infusion with beneficial effects in the treatment of light to medium forms of respiratory diseases (dry cough, viral infections). The fir buds syrup is prepared only from fresh buds either by cold pressing or by thermal treatment (boiling). The syrup can be used as a sweetener and/or taste enhancer in teas or diluted with water as a refreshing and tonic drink, having similar beneficial properties as the fir buds infusion. Fir buds extract is one of the most important products in gemmotherapy being recommended in the prophylaxis and treatment of the main childhood disorders: rickets, bone pains, dental caries, anemia (Sorescu et al., 2012; Bojor and Popescu, 2004).
Aims and objectives. Consumers' interest in natural remedies for different health issues is increasing but also is their awareness in choosing quality products. The aim of the present study was to assess the antioxidant capacity and the antimicrobial properties of fir buds syrup obtained by cold pressing and by thermal treatment. To achieve the proposed goal, the content in vitamin C, flavonoids, antioxidant capacity and antimicrobial activity were determined for the analyzed samples.

Materials and methods. Two types of fir tree buds syrup were taken into study: one obtained by cold pressing (FS-CP) and the other one produced by subjecting the fir tree buds to thermal treatment (FS-T). The antioxidant capacity of fir tree buds syrup samples was assessed through the evaluation of free radical scavenging effect on 2,2-diphenyl-1-picrylhydrazyl (DPPH) radical (Kim et al., 2010). Shortly, $10 \mathrm{ml}$ of syrup were extracted with $10 \mathrm{ml}$ of methanol solution. Aliquots of methanolic extracts were mixed with methanolic DPPH solution. After 30 minutes incubation in darkness, the absorbance of each sample was measured on a Shimadzu UV-1700 PharmaSpec spectrophotometer at $515 \mathrm{~nm}$ against 
a blank of methanol. Results were expressed as the percentage of decrease in the absorbance value of each sample compared with the absorbance of DPPH reference solution. The methanolic extracts of the syrup samples were further used for the determination of flavonoids content. The analysis of flavonoids was performed using a chromogenic system of $\mathrm{NaNO}_{2}-\mathrm{Al}(\mathrm{NO} 3)_{3}-\mathrm{NaOH}$ and reading the absorbance of the formed pink or purple complex at $500 \mathrm{~nm}$ against a blank sample without coloration (Zhu et al., 2010). The concentration in flavonoids compounds of each sample was expressed as mg of quercetin equivalents per $100 \mathrm{ml}$ of fir bud syrup (mg QE/100mL). For the determination of vitamin C content, $10 \mathrm{ml}$ of syrup sample were extracted with $2 \% \mathrm{HCl}$ solution followed by titration with potassium iodate solution till blue coloration. The results were expressed as $\mathrm{mg}$ of vitamin $C$ per $100 \mathrm{ml}$ of syrup. The antimicrobial activity was performed using five strains (E.coli, B. cereus, S.aureus, L. monocytogenes, Salmonella thypi) that were tested by disc diffusion method. The test microorganism were seeded into respective medium by spread plate method $10 \mu \mathrm{l}$ $\left(10^{6}\right.$ cells $\left./ \mathrm{ml}\right)$ with $24 \mathrm{~h}$ cultures of bacteria growth in nutrient broth. After solidification the filter paper discs (5 $\mathrm{mm}$ in diameter) impregnated with the extracts were placed on test organism-seeded plates. Steptomycin sulphate $\left(10 \mu \mathrm{g} \mathrm{ml}^{-1}\right)$ used as positive control. The antimicrobial assay plates were incubated at $37^{\circ} \mathrm{C}$ for $24 \mathrm{~h}$. The diameters of inhibition zones were measured in $\mathrm{mm}$.

Results and Discussion. The thermal treatment (boiling) applied in the case of FS-T has greatly influenced the content in vitamin $\mathrm{C}$ and flavonoids of the samples. Thus, the vitamin $\mathrm{C}$ content of the FS-CP samples was two times higher than that of FS-T samples $(40.48 \mathrm{mg} / 100 \mathrm{ml}$, respectively $21.12 \mathrm{mg} / 100 \mathrm{ml}$ ). A decrease in the concentration of flavonoids was also observed. In the case of FS-CP samples, the determined level of flavonoids was of $60.9 \mathrm{mg}$ QE $/ 100 \mathrm{ml}$ syrup, while for FS-T samples was of $39.9 \mathrm{mg}$ QE/ 100mL syrup. Although the FS-T samples had lower contents in vitamin $\mathrm{C}$ and flavonoids, their radical scavenging activity was with only $3.8 \%$ smaller than the radical scavenging activity of FS-CP samples (18.59\%, respectively $22.4 \%$ ). The results obtained in the present study relieved that the tested two types of fir buds syrups posses potential antibacterial activity against $E$.coli, $B$. cereus, S. aureus, L. monocytogenes, Salmonella thypi being in agreement with those reported by Mahesh and Satish, 2008. When tested by the disc diffusion method, the fresh fir buds syrup showed significant activity against $B$. cereus, $S$. aureus, $L$. monocytogenes while the thermal processed fir buds syrup showed significant activity against $S$. aureus, L. monocytogenes.

Conclusions. The fir bud syrup obtained by thermal treatment showed a decrease in the bioactive compounds content (vitamin $\mathrm{C}$ and flavonoids) compared with the syrup obtained by cold pressing, but their antioxidant capacity remained almost equal. Also both types of fir buds syrups showed significant antibacterial activity against $B$. cereus, $S$. aureus, L. monocytogenes.

\section{REFERENCES}

1. Bojor, O. and Popescu, O. (2004). Fitoterapie tradiţională și modern. Editura Fiat Flux, București.

2. Kim, N-Y. et al. (2010). Comparison of methods for proanthocyanidin extraction from pine (Pinus densiflora) needles and biological activities of the extracts, Nutr. Res. Pract., 4(1): 16-22.

3. Mahesh, B. and Satish, S. (2008). Antimicrobial activity of some important medicinal plant against plant and human pathogens, World. J. Agri. Sci., 4(S):839-843.

4. Sorescu, S. et al. (2012). Gemoterapia de la A la Z, Editura Eikon, Cluj-Napoca.

5. Zhu, H. et al. (2009). Analysis of Flavonoids in Portulaca oleracea L. by UV-Vis Spectrophotometry with comparative study on different extraction technologies, Food Anal. Methods, 3: 90-97. 